R. E. Hobart, "Free Will as Involving Determination and Inconceivable Without It," Mind, New Series, Vol. 43, No. 169. (Jan., 1934), pp. 1-27.

\section{FREE WILL AS INVOLVING DETERMINATION AND INCONCEIVABLE WITHOUT IT}

\section{R. E. HOBART (Dickinson S. Miller)}

The thesis of this article is that there has never been any ground for the controversy between the doctrine of free will and determinism, that it is based upon a misapprehension, that the two assertions are entirely consistent, that one of them strictly implies the other, that they have been opposed only because of our natural want of the analytical imagination. In so saying I do not tamper with the meaning of either phrase. That would be unpardonable. I mean free will in the natural and usual sense, in the fullest, the most absolute sense in which for the purposes of the personal and moral life the term is ever employed. I mean it as implying responsibility, merit and demerit, guilt and desert. I mean it as implying, after an act has been performed, that one "could have done otherwise" than one did. I mean it as conveying these things also, not in any subtly modified sense but in exactly the sense in which we conceive them in life and in law and in ethics. These two doctrines have been opposed because we have not realised that free will can be analysed without being destroyed, and that determinism is merely a feature of the analysis of it. And if we are tempted to take refuge in the thought of an "ultimate", an "innermost" liberty that eludes the analysis, then we have implied a deterministic basis and constitution for this liberty as well. For such a basis and constitution lie in the idea of liberty.

The thesis is not, like that of Green or Bradley, that the contending opinions are reconciled if we adopt a certain metaphysic of the ego, as that it is timeless, and identifies itself with a desire by a "timeless act". This is to say that the two are irreconcilable, as they are popularly supposed to be, except by a theory that delivers us from the conflict by taking us out of time. Our view on the contrary is that from the natural and temporal point of view itself there never was any need of a reconciliation but only of a comprehension of the meaning of terms. (The metaphysical nature of the self and its identity through time is a problem for all who confront memory, anticipation, etc.; it has no peculiar difficulties arising from the present problem.)

I am not maintaining that determinism is true; only that it is true in so far as we have free will. That we are free in willing is, broadly speaking, a fact of experience. That broad fact is more assured than any philosophical analysis. It is therefore surer than the deterministic analysis of it, entirely adequate as that in the end appears to be. But it is not here affirmed that there are no small exceptions, no slight undetermined swervings, no ingredient of absolute chance. All that is here said is that such absence of determination, if and so far as it exists, is no gain to freedom, but sheer loss of it; no advantage to the moral life, but blank subtraction from it. - When I speak below of "the indeterminist" I mean the libertarian indeterminist, that is, him who believes in free will and holds that it involves indetermination.

By the analytical imagination is meant, of course, the power we have, not by nature but by training, of realising that the component parts of a thing or process, taken together, each in its place, with their relations, are identical with the thing or process itself. If it is "more than its parts", then this "more" will appear in the analysis. It is not true, of course, that all facts are susceptible of analysis, but so far as they are, there is occasion for the analytical, imagination. We have been accustomed to think of a thing or a person as a whole, not as a combination of parts. We have been accustomed to think of its activities as the way 
in which, as a whole, it naturally and obviously behaves. It is a new, an unfamiliar and an awkward act on the mind's part to consider it, not as one thing acting in its natural manner, but as a system of parts that work together in a complicated process. Analysis often seems at first to have taken away the individuality of the thing, its unity, the impression of the familiar identity. For a simple mind this is strikingly true of the analysis of a complicated machine. The reader may recall Paulsen's ever significant story about the introduction of the railway into Germany. When it reached the village of a certain enlightened pastor, he took his people to where a locomotive engine was standing, and in the clearest words explained of what parts it consisted and how it worked. He was much pleased by their eager nods of intelligence as he proceeded. But on his finishing they said: "Yes. Yes, Herr Pastor, but there's a horse inside, isn't there?" They could not realise the analysis. They were wanting in the analytical imagination. Why not? They had never been trained to it. It is in the first instance a great effort to think of all the parts working together to produce the simple result that the engine glides down the track. It is easy to think of a horse inside doing all the work. A horse is a familiar totality that does familiar things. They could no better have grasped the physiological analysis of a horse's movements had it been set forth to them.

The reason for thinking that there is no occasion for the controversy lies exclusively in the analysis of the terms employed in it. But the several analyses must all be taken together, realised jointly, before the position can be fully understood.

Self and Character. - We are not concerned with the total nature of the self, but only with the aspect of it strictly involved in our question. We are not dealing with the problem of knowledge and therefore not with the self as mere knower. It is clear that the self merely as knower in general (irrespective of just what particulars it knows) is similar in all men. The relation of subject to object, whatever it may be, is the same with you and with me. But the self as it interests ethics is not the same in different persons. It is the concrete, active self, existing through time and differing from others. The whole stress of morality arises because moral selves are not alike, because there is need of influencing some moral selves to make them refrain from certain acts or neglects, that is, in order to make them better moral selves. How do we express the difference? We call it a difference of moral qualities, traits, or character. We are having regard to the question what acts will come from these selves. By character we mean - do we not? - the sum of a man's tendencies to action, considered in their relative strength; or that sum in so far as it bears upon morals.

Now the position of the indeterminist is that a free act-of-will is the act of the self. The self becomes through it the author of the physical act that ensues. This volition of the self causes the physical act but it is not in its turn caused, it is "spontaneous". To regard it as caused would be determinism. The causing self to which the indeterminist here refers is to be conceived as distinct from character; distinct from temperament, wishes, habits, impulses. He emphasises two things equally: the physical act springs from the self through its volition, and it does not spring merely from character, it is not simply the result of character and circumstances. If we ask, "Was there anything that induced the self thus to act?" we are answered in effect, "Not definitively. The self feels motives but its act is not determined by them. It can choose between them."

The next thing to notice is that this position of the indeterminist is taken in defence of moral conceptions. There would be no fitness, he says, in our reproaching ourselves, in our feeling remorse, in our holding ourselves or 
anyone guilty, if the act in question were not the act of the self instead of a product of the machinery of motives.

We have here one of the most remarkable and instructive examples of something in which the history of philosophy abounds - of a persistent, an age-long deadlock due solely to the indisposition of the human mind to look closely into the meaning of its terms.

How do we reproach ourselves? We say to ourselves, "How negligent of me!" "How thoughtless!" "How selfish!" "How hasty and unrestrained!" "That I should have been capable even for a moment of taking such a petty, irritated view!" etc. In other words, we are attributing to ourselves at the time of the act, in some respect and measure, a bad character, and regretting it. And that is the entire point of our self-reproach. We are turning upon ourselves with disapproval and it may be with disgust; we wish we could undo what we did in the past, and, helpless to do that, feel a peculiar thwarted poignant anger and shame at ourselves that we had it in us to perpetrate the thing we now condemn. It is self we are reproaching, i.e., self that we are viewing as bad in that it produced bad actions. Except in so far as what-it-is produced these bad actions, there is no ground for reproaching it (calling it bad) and no meaning in doing so. All self-reproach is self-judging, and all judging is imputing a character. We are blaming ourselves. If spoken, what we are thinking would be dispraise. And what are praise and dispraise? Always, everywhere, they are descriptions of a person (more or less explicit) with favourable or unfavourable feeling at what is described, - descriptions in terms of value comporting fact, or of fact comporting value, or of both fact and value. In moral instances they are descriptions of his character. We are morally characterising him in our minds (as above) with appropriate feelings. We are attributing to him the character that we approve and like and wish to see more of, or the contrary. All the most intimate terms of the moral life imply that the act has proceeded from me, the distinctive me, from the manner of man I am or was. And this is the very thing on which the libertarian lays stress. What the indeterminist prizes with all his heart, what he stoutly affirms and insists upon, is precisely what he denies, namely, that I, the concrete and specific moral being, am the author, the source of my acts. For, of course, that is determinism. To say that they come from the self is to say that they are determined by the self - the moral self, the self with a moral quality. He gives our preferrings the bad name of the machinery of motives, but they are just what we feel in ourselves when we decide. When he maintains that the self at the moment of decision may act to some extent independently of motives, and is good, or bad according as it acts in this direction or that, he is simply setting up one character within another, he is separating the self from what he understands by the person's character as at first mentioned, only thereupon to attribute to it a character of its own, in that he judges it good or bad.

The whole controversy is maintained by the indeterminist in order to defend the validity of the terms in which we morally judge, - for example, ourselves. But the very essence of all judgment, just so far as it extends, asserts determination.

If in conceiving the self you detach it from all motives or tendencies, what you have is not a morally admirable or condemnable, not a morally characterisable self at all. Hence it is not subject to reproach. You cannot call a self 'good' because of its courageous free action, and then deny that its action was determined by its character. In calling it good because of that action you have implied that the action came from its goodness (which means its good character) and was a sign thereof. By their fruits ye shall know them. The indeterminist 
appears to imagine that he can distinguish the moral "I" from all its propensities, regard its act as arising in the moment undetermined by them, and yet can then (for the first time, in his opinion, with propriety!) ascribe to this "I" an admirable quality. At the very root of his doctrine he contradicts himself. How odd that he never catches sight of that contradiction! He fights for his doctrine in order that he may call a man 'morally good' on account of his acts, with some real meaning; and his doctrine is that a man's acts (precisely so far as "free" or undetermined) do not come from his goodness. So they do not entitle us to call him good. He has taken my position in defence of moral conceptions, and it is fatal to all moral conceptions.

We are told, however, that it is under determinism that we should have no right any more to praise or to blame. At least we could not do so in the old sense of the terms. We might throw words of praise to a man, or throw words of blame at him, because we know from observation that they will affect his action; but the old light of meaning in the terms has gone out. Well, all we have to do is to keep asking what this old meaning was. We praise a man by saying that he is a good friend, or a hard worker, or a competent man of business, or a trusty assistant, or a judicious minister, or a gifted poet, or one of the noblest of men - one of the noblest of characters. In other words, he is a being with such and such qualities. If it is moral praise, he is a being with such and such tendencies to bring forth good acts. If we describe a single act, saying, for instance: "Well done!" we mean to praise the person for the act as being the author of it. It is he who has done well and proved himself capable of doing so. If the happy act is accidental we say that no praise is deserved for it. If a person is gratified by praise it is because of the estimate of him, in some respect or in general, that is conveyed. Praise (once again) means description, with expressed or implied admiration. If any instance of it can be found which does not consist in these elements our analysis fails. "Praise the Lord, O my soul, and forget not all His benefits", - and the Psalm goes on to tell His loving and guarding acts toward humankind. To praise the Lord is to tell His perfections, especially the perfections of His character. This is the old light that has always been in words of praise and there appears no reason for its going out.

Indeterminism maintains that we need not be impelled to action by our wishes, that our active will need not be determined by them. Motives "incline without necessitating". We choose amongst the ideas of action before us, but need not choose solely according to the attraction of desire, in however wide a sense that word is used. Our inmost self may rise up in its autonomy and moral dignity, independently of motives, and register its sovereign decree.

Now, in so far as this "interposition of the self" is undetermined, the act is not its act, it does not issue from any concrete continuing self; it is born at the moment, of nothing, hence it expresses no quality; it bursts into being from no source. The self does not register its decree, for the decree is not the product of just that "it." The self does not rise up in its moral dignity, for dignity is the quality of an enduring being, influencing its actions, and therefore expressed by them, and that would be determination. In proportion as an act of volition starts of itself without cause it is exactly, so far as the freedom of the individual is concerned, as if it had been thrown into his mind from without "suggested" to him - by a freakish demon. It is exactly like it in this respect, that in neither case does the volition arise from what the man is, cares for or feels allegiance to; it does not come out of him. In proportion as it is undetermined, it is just as if ,his legs should suddenly spring up and carry him off where he did not1 prefer to go. Far from constituting 
freedom, that would mean, in the exact measure in which it took place, the loss of freedom. It would be an interference, and an utterly uncontrollable interference, with his power of acting as he prefers. In fine, then, just so far as the volition is undetermined, the self can neither be praised nor blamed for it, since it is not the act of the self.

The principle of free will says: "I produce my volitions". Determinism says: "My volitions are produced by me". Determinism is free will expressed in the passive voice.

After all, it is plain what the indeterminists have done. It has not occurred to them that our free will may be resolved into its component elements. (Thus far a portion only of this resolution has been considered.) When it is thus resolved they do not recognise it. The analytical imagination is considerably taxed to perceive the identity of the free power that we feel with the component parts that analysis shows us. We are gratified by their nods of intelligence and their bright, eager faces as the analysis proceeds, but at the close are a little disheartened to find them falling back on the innocent supposition of a horse inside that does all the essential work. They forget that they may be called upon to analyse the horse. They solve the problem by forgetting analysis. The solution they offer is merely: "There is a self inside which does the deciding". Or, let us say, it is as if the Pfarrer were explaining the physiology of a horse's motion. They take the whole thing to be analysed, imagine a duplicate of it reduced in size, so to speak, and place this duplicate-self inside as an explanation - making it the elusive source of the" free decisions ". They do not see that they are merely pushing the question a little further back, since the process of deciding, with its constituent factors, must have taken place within that inner self. Either it decided in, a particular way because, on the whole, it preferred to decide in that way, or the decision was an underived event, a rootless and sourceless event. It is the same story over again. In neither case is there any gain in imagining a second self inside, however wonderful and elusive. Of course, it is the first alternative that the indeterminist is really imagining. If you tacitly and obscurely conceive the self as deciding its own way, i.e., according to its preference, but never admit or recognise this, then you can happily remain a libertarian indeterminist; but upon no other terms. In your theory there is a heart of darkness.

Freedom. - In accordance with the genius of language, free will means freedom of persons in willing, just as "free trade" means freedom of persons (in a certain respect) in trading. The freedom of anyone surely always implies his possession of a power, and means the absence of any interference (whether taking the form of restraint or constraint) with his exercise of that power. Let us consider this in relation to freedom in willing.

"Can". - We say, "I can will this or I can will that, whichever I choose". Two courses of action present themselves to my mind. I think of their consequences, I look on this picture and on that, one of them commends itself more than the other, and I will an act that brings it about. I knew that I could choose either. That means that I had the power to choose either.

What is the meaning of "power"? A person has a power if it is a fact that when he sets himself in the appropriate manner to produce a certain event that event will actually follow. I have the power to lift the lamp; that is, if I grasp it and exert an upward pressure with my arm, it will rise. I have the power to will so and so; that is, if I want, that act-of-will will take place. That and none other is the meaning of power, is it riot? A man's being in the proper active posture of body or of mind is the cause, and the sequel in question will be the effect. (Of course, it may be held that the sequel not only does but must 
follow, in a sense opposed to Hume's doctrine of cause. Very well; the question does not here concern us.)

Thus power depends upon, or rather consists in, a law. The law in question takes the familiar form that if something happens a certain something else will ensue. If $A$ happens then $B$ will happen. The law in this case is that if the man definitively so desires then volition will come to pass. There is a series, wish - will act. The act follows according to the will (that is a law, - I do not mean an underived law) and the will follows according to the wish (that is another law). A man has the power (sometimes) to act as he wishes. He has the power (whenever he is not physically bound or held) to act as he wills. He has the power always (except in certain morbid states) to will as he wishes. All this depends upon the laws of his being. Wherever there is a power there is a law. In it the power wholly consists. A man's power to will as he wishes is simply the law that his will follows his wish.

What, again, does freedom mean? It means the absence of any interference with all this. Nothing steps in to prevent my exercising my power. ${ }^{1}$

All turns on the meaning of 'can'. "I can will either this or that" means, I am so constituted that if I definitively incline to this, the appropriate act-of-will will take place, and if I definitively incline to that, the appropriate actof-will will take place. The law connecting preference and will exists, and there is nothing

\footnotetext{
${ }^{1}$ A word as to the relation of power and freedom. Strictly power cannot exist without freedom, since the result does-not follow without it. Freedom on the other hand is a negative term, meaning the absence of something, and implies a power only because that whose absence it signifies is interference, which implies something to be interfered with. Apart from this peculiarity of the term itself, there might be freedom without any
}

to interfere with it. My free power, then, is not an exemption from law but in its inmost essence an embodiment of law.

Thus it is true, after the act-of-will, that I could have willed otherwise. It is most natural to add, "if I had wanted to"; but the addition is not required. The point is the meaning of "could". I could have willed whichever way I pleased. I had the power to will otherwise, there was nothing to prevent my doing so, and I should have done so if I had wanted. If someone says that the wish I actually had prevented my willing otherwise, so that I could not have done it, he is merely making a slip in the use of the word "could". He means, that wish could not have produced anything but this volition. But "could" is asserted not of the wish (a transient fact to which power in this sense is not and should not be ascribed) but of the person. And the person could have produced something else than that volition. He could have produced any volition he wanted; he had the power to do so.

But the objector will say, "The person as he was at the moment - the person as animated by that wish - could not have produced any other volition". Oh, yes, he could. "Could" has meaning not as applied to a momentary actual phase of a person's life, but to the person himself of whose life that is but a phase; and it means that (even at that moment) he had the power to will just as he preferred. The idea of power, because it is the idea of a law, is hypothetical, carries in itself hypothesis as part of its very intent and meaning - "if he should prefer this, if he should prefer that", - and

power. Absence of interference (of what would be interference if there were a power) might exist in the absence of a power; a man might be free to do something because there was nothing to interfere with his doing it, but might have no power to do it. Similarly and conveniently we may speak of a power as existing though interfered with; that is, the law may exist that would constitute a power if the interference were away. 
therefore can be truly applied to a person irrespective of what at the moment he does prefer. It remains hypothetical even when applied. ${ }^{2}$ This very peculiarity of its meaning is the whole point of the idea of power. It is just because determinism is true, because a law obtains, that one "could have done otherwise".

Sidgwick set over against "the formidable array of cumulative evidence" offered for determinism the "affirmation of consciousness" "that I can now choose to do" what is right and reasonable, "however strong may be my inclination to act unreasonably" (Sidgwick 65). But it is not against determinism. It is a true affirmation (surely not, of immediate consciousness but of experience), the affirmation of my power to will what I deem right, however intense and insistent my desire for the wrong. I can will anything, and can will effectively anything that my body will enact. I can will it despite an inclination to the contrary of any strength you please - strength as felt by me before decision. We all know cases where we have resisted impulses of great strength in this sense and we can imagine them still stronger. I have the power to do it, and shall do. it, shall exercise that power, if I prefer. Obviously in that case (be it psychologically remarked) my solicitude to do what is right will have proved itself even stronger (as measured by ultimate tendency to prevail, though not of necessity by sensible vividness or intensity) than the inclination to the contrary, for that is what is meant by my preferring to do it. I am conscious that the field for willing is open; I can will anything that I elect to will. Sidgwick did not analyse the meaning of "can", that is all. He did not precisely catch the outlook of consciousness when it says, "I can". He did not distinguish the function of the word, which is to express

\footnotetext{
${ }^{2} \mathrm{I}$ am encouraged by finding in effect the same remark in Prof. G. E. Moore's Ethics, Ch. vi., at least as regards what he terms one sense of the
}

the availability of the alternatives I see when, before I have willed, and perhaps before my preference is decided, I look out on the field of conceivable volition. He did not recognise that I must have a word to express my power to will as I please, quite irrespective of what I shall please, and that "can" is that word. It is no proof that I cannot do something to point out that I shall not do it if I do not prefer. A man, let us say, can turn on the electric light; but he will not turn it on if he walks away from it; though it is still true that he can turn it on. When we attribute power to a man we do not mean that something will accomplish itself without his wanting it to. That would never suggest the idea of power. We mean that if he makes the requisite move the thing will be accomplished. It is part of the idea that the initiative shall rest with him. The initiative for an act-of-will is a precedent phase of consciousness that we call the definitive inclination, or, in case of conflict, the definitive preference for it. If someone in the throes of struggle with temptation says to himself, "I can put this behind me", he is saying truth and precisely the pertinent truth. He is bringing before his mind the act-of-will, unprevented, quite open to him, that would deliver him from what he deems noxious. It may still happen that the noxiousness of the temptation does not affect him so powerfully as its allurement, and that he succumbs. It is no whit less true, according to determinism, that he could have willed otherwise. To analyse the fact expressed by "could" is not to destroy it.

But it may be asked, "Can I will in opposition to my strongest desire at the moment when it is strongest?" If the words "at the moment when it is strongest" qualify "can", the answer has already been given. If they qualify "will", the suggestion is a contradiction in terms. Can I

word "could". I should hazard saying, the only sense in this context (Moore). 
turn-on-the-electric-light-at-a-moment-when-Iam-not-trying-to-do-so? This means, if I try to turn on the light at a moment when I am not trying to, will it be turned on? A possible willing as I do not prefer to will is not a power on my part, hence not to be expressed by "I can".

Everybody knows that we often will what we do not want to will, what we do not prefer. But when we say this we are using words in another sense than that in which I have just used them. In one sense of the words, whenever we act we are doing what we prefer, on the whole, in view of all the circumstances. We are acting for the greatest good or the least evil or a mixture of these. In the other and more usual sense of the words, we are very often doing what we do not wish to do, i.e., doing some particular thing we do not wish because we are afraid of the consequences or disapprove of the moral complexion of the particular thing we do wish. We do the thing that we do not like because the other thing has aspects that we dislike yet more. We are still doing what we like best on the whole. It is again a question of the meaning of words.

If the initiative for volition is not a wish, what is it? Indeterminism says that a moral agent sometimes decides against the more tempting course. He does so, let us say, because it is wrong, the other course is the right one. In other words, the desire to do right is at the critical moment stronger within him than the temptation. No, no, replies indeterminism, it is not that; he sometimes decides against the stronger desire. Very well; "can" meaning what it does, tell us what is the leaning or favourable disposition on the part of the ego, in a case of undetermined willing, toward the volition it adopts; what is that which constitutes the ego's initiative in that direction, - since it is not a wish? Shall we say it is an approval or conscientious acceptance? Does this approval or acceptance arise from the agent's distinctive moral being? That is determinism, quite as much as if you called the initiative a wish. But the indeterminist has already answered in effect that there is no such initiative, or no effectual initiative. The act-ofwill causes the physical act but is not itself caused. This is to deny the presence of power, according to its definition. How has it a meaning to say in advance that "I can" will this way or that? The self, considering the alternatives beforehand, is not in a position to say, "If I feel thus about it, this volition will take place, or if I feel otherwise the contrary will take place; I know very well how I shall feel, so I know how I shall will". The self now existing has not control over the future "free" volition, since that may be undetermined, nor will the self's future feelings, whatever they may be, control it. Hence the sense expressed by "I can", the sense of power inhering in one's continuous self to sway the volition as it feels disposed, is denied to it. All it is in a position to mean by "I can" is, "I do not know which will happen", which is not "I can" at all. Nay, even looking backward, it is unable to say: "I could have willed otherwise", for that clearly implies, "Had I been so disposed the other volition would have taken place", which is just what cannot, according to indeterminism, be said. Surely, to paraphrase a historic remark, our "liberty" does not seem to be of very much use to us. The indeterminist is in a peculiarly hapless position. The two things that he is most deeply moved to aver, that the free volition is the act of the self, and that the self can will one way or the other - these two things on my own theory fall utterly to pieces, and can only be maintained on the view that he opposes.

Compulsion. - The indeterminist conceives that according to determinism the self is carried along by wishes to acts which it is thus necessitated to perform. This mode of speaking distinguishes the self from the wishes and represents it as under their dominion. This is the initial error. This is what leads the 
indeterminist wrong on all the topics of his problem. And the error persists in the most recent writings. In fact, the moral self is the wishing self. The wishes are its .own. It cannot be described as under their dominion, for it has no separate predilections to be overborne by them; they themselves are its predilections. To fancy that because the person acts according to them he is compelled, a slave, the victim of a power from whose clutches he cannot extricate himself, is a confusion of ideas, a mere slip of the mind. The answer that has ordinarily been given is surely correct; all compulsion is causation, but not all causation is compulsion. Seize a man and violently force him to do something, and he is compelled - also caused - to do it. But induce him to do it by giving him reasons and his doing it is caused but not compelled.

Passivity. - We have to be on our guard even against conceiving the inducement as a cause acting like the impact of a billiard ball, by which the self is precipitated into action like a second billiard ball, as an effect. The case is not so simple. Your reasons have shown him that his own preferences require the action. He does it of his own choice; he acts from his own motives in the light of your reasons. The sequence of cause and effect goes on within the self, with contributory information from without.

It is not clarifying to ask, "Is a volition free or determined?" It is the person who is free, and his particular volition that is determined. Freedom is something that we can attribute only to a continuing being, and he can have it only so far as the particular transient volitions within him are determined. (According to the strict proprieties of language, it is surely events that are caused, not things or persons; a person or thing can be caused or determined only in the sense that its beginning-to-be, or changes in it, are caused or determined.)
It is fancied that, owing to the "necessity" with which an effect follows upon its cause, if my acts of will are caused I am not free in thus acting. Consider an analogous matter. When I move I use ligaments. "Ligament" means that which binds, and a ligament does bind bones together. But I am not bound. I (so far as my organism is concerned) am rendered possible by the fact that my bones are bound one to another; that is part of the secret of my being able to act, to move about and work my will. If my bones ceased to be bound one to another I should be undone indeed. The human organism is detached, but it is distinctly important that its component parts shall not be detached. Just so my free power of willing is built up of tight cause-and-effect connections. The point is that when I employ the power thus constituted nothing determines the particular employment of it but me. Bach particular act of mine is determined from outside itself, i.e., by a cause, a prior event. But not from outside me. I, the possessor of the power, am not in my acts passively played upon by causes outside me, but am enacting my own wishes in virtue of a chain of causation within me. What is needed is to distinguish broadly between a particular effect, on the one hand, and, on the other, the detached, continuous life of a mental individual and his organism; a life reactive, but reacting according to its own nature.

What makes the other party uncontrollably reject all this - let us never forget - is the words. They smell of sordid detail, "of unwinsome psychological machinery". They are not bathed in moral value, not elevated and glowing. In this the opponents' instinct is wholly right; only when they look for the value they fail to focus their eyes aright. It is in the whole act and the whole trait and the whole being that excellence and preciousness inhere; analysis must needs show us elements which, taken severally, are without moral expressiveness; as would be even the celestial anatomy of an angel appearing on earth. The 
analytic imagination, however, enables us to see the identity of the living fact in its composition with the living fact in its unity and integrity. Hence we can resume the thought of it as a unit and the appropriate feelings without fancying that analysis threatens them or is at enmity with them.

Spontaneity. - The conception of spontaneity in an act or an utterance is the conception of its springing straight from the being' himself, from his individuality, with naught to cause it but the freest impulse, the sheerest inclination, of that being. The term implies and requires but one causation, that from within. If we deny all causation behind the volition itself, even that from within his nature, we deny spontaneity on his part. We have emptied our formula of all human meaning.

Source. - The indeterminist declares a man to be "the absolute source" of his acts. Let us scrutinise the term. The source of a stream is not a point where the water constituting the stream comes suddenly into existence, but on the contrary that from which it issues, that which supplies it because it has contained it. The stream - that particular stream — begins there, just as the action begins at its source, though the active energy flows from within it. The word "absolute" must mean true, genuine, complete, without reservation or qualification. Now such a genuine source a man in fact is; he knowingly and deliberately creates an act; the act issues forth from his chosen purpose, from his moral individuality. What the indeterminist, however, must mean by "absolute source" is a source that has in turn no source; a source, he thinks, cannot in the fullest and truest sense be such if it derives what it emits. This, as we see, certainly receives no support from the natural uses of the word, but is flatly incompatible with them. But the final objection is deeper. Will the indeterminist point out anything in the definition of the word "source" which implies that the thing defined is itself sourceless, or is imperfectly realised if it has a source? If he cannot, then the addition of the word "absolute" does not import that sourcelessness into the idea. Obviously "the man", as figuring in the indeterminist's conception here, would have to be the momentary man, not the enduring moral being. The truth clearly is that the indeterminist is confusing the idea of flowing from this source and previously from another with the quite distinct idea of not flowing from this source but from another. He feels that they cannot both be sources of the same act. And this is part of his confusion between causation and compulsion. If the agent were, compelled to act as he does, not he but the compeller would be the intentional, the moral source of the act.

Prediction. - If we knew a man's character thoroughly and the circumstances that he would encounter, determinism (which we are not here completely asserting) says that we could foretell his conduct. This is a thought that repels many libertarians. Yet to predict a person's conduct need not be repellent. If you are to be alone in a room with $£ 1000$ belonging to another on the table and can pocket it without anyone knowing the fact, and if I predict that you will surely not pocket it, that is not an insult. I say, I know you, I know your character; you will not do it. But if I say that you are "a free being" and that I really do not know whether you will pocket it or not, that is rather an insult. On the other hand, there are cases where prediction is really disparaging. If I say when you make a remark, "I knew you were going to say that", the impression is not agreeable. My exclamation seems to say that your mind is so small and simple that one can predict its ideas. That is the real reason why people resent in such cases our predicting their conduct; that if present human knowledge, which is known to be so limited, can foresee their conduct, it must be more naive and 
stereotyped than they like to think it. It is no reflection upon the human mind or its freedom to say that one who knew it through and through (a human impossibility) could foreknow its preferences and its spontaneous choice. It is of the very best of men that even we human beings say, "I am sure of him". It has perhaps in this controversy hardly been observed how much at this point is involved, how far the question of prediction reaches. The word "reliable" or "trustworthy" is a prediction of behaviour. Indeed, all judgment of persons whatever, in the measure of its definitude, is such a prediction.

Material Fate. - The philosopher in the old story, gazing at the stars, falls into a pit. We have to notice the pitfall in our subject to which, similarly occupied, Prof. Eddington has succumbed.

"What significance is there in my mental struggle to-night whether I shall or shall not give up smoking, if the laws which govern the matter of the physical universe already preordain for the morrow a configuration of matter consisting of pipe, tobacco, and smoke connected with my lips?" (Eddington 41)

No laws, according to determinism, pre-ordain such a configuration, unless I give up the struggle. Let us put matter aside for the moment, to return to it. Fatalism says that my morrow is determined no matter how I struggle. This is of course a superstition. Determinism says that my morrow is determined through my struggle. There is this significance in my mental effort, that it is deciding the event. The stream of causation runs through my deliberations and decision, and, if it did not run as it does run, the event would be different. The past cannot determine the event except through the present. And no past moment determined it any more truly than does the present moment. In other words, each of the links in the causal chain must be in its place. Determinism (which, the reader will remember, we have not here taken for necessarily true in all detail) says that the coming result is "pre-ordained" (literally, caused) at each stage, and therefore the whole following series for to-morrow may be described as already determined; so that did we know all about the straggler, how strong of purpose he was and how he was influenced (which is humanly impossible) we could tell what he would do. But for the straggler this fact (supposing it to be such) is not pertinent. If, believing it, he ceases to struggle, he is merely revealing that the forces within him have brought about that cessation. If on the other hand he struggles manfully he will reveal the fact that they have brought about his success. Since the causation of the outcome works through his struggle in either case equally, it cannot become for him a moving consideration in the struggle. In it the question is, "Shall I do this or that?" It must be answered in the light of what there is to recommend to me this or that. To this question the scientific truth (according to determinism) that the deliberation itself is a play of causation is completely irrelevant; it merely draws the mind delusively away from the only considerations that concern it.

As regards the role of matter in the affair, if, as Prof. Eddington on behalf of the determinists is here supposing, the behaviour of all matter, including the human organism, takes place according to a deterministic scheme of physical law, then we must conceive, according to the familiar formula, that the mental process is paralleled in the brain by a physical process. The whole psycho-physical occurrence would then be the cause of what followed, and the psychic side of it, the mental struggle proper, a con-cause or side of the cause. To-morrow's configuration of matter will have been brought about by a material process with which the mental process was inseparably conjoined. I make this supposition merely to show that 
supposing the existence of a physically complete mechanism through which all human action is caused and carried out has no tendency to turn determinism into fatalism. For the mental struggle must in that case be paralleled by a physical straggle which, so to speak, represents it and is in a manner its agent in the physical world; and upon this struggle the physical outcome will depend. (The determinist need not, but may of course, hold this doctrine of automatism, of a physically complete mechanism in human action.)

\section{Self as Product and Producer. -} We can at this stage clearly see the position when a certain very familiar objection is raised. "How can any one be praised or blamed if he was framed by nature as he is, if heredity and circumstance have given him his qualities? A man can surely be blamed only for what he does himself, and he did not make his original character; he simply found it on his hands." A man is to be blamed only for what he does himself, for that alone tells what he is. He did not make his character; no, but he made his acts. Nobody blames him for making such a character, but only for making such acts. And to blame him for that is simply to say that he is a bad act-maker. If he thinks the blame misapplied he has to prove that he is not that sort of an act-maker. Are we to be told that we may not recognise what he is, with appropriate feelings for its quality, because he did not create himself - a mere contortion and intussusception of ideas? The moral self cannot be causa sui. To cause his original self a man must have existed before his original self. Is there something humiliating to him in the fact that he is not a contradiction in terms? If there were a being who made his "original character", and made a fine one, and we proceeded to praise him for it, our language would turn out to be a warm ascription to him of a still earlier character, so that the other would not have been original at all. To be praised or blamed you have to be; and be a particular person; and the praise or blame is telling what land of a person you are. There is no other meaning to be extracted from it. Of course, a man does exist before his later self, and in that other sense he can be a moral causa sui. If by unflagging moral effort he achieves for himself better subsequent qualities, what can merit praise but the ingredient in him of aspiration and resolution that was behind the effort? If he should even remake almost his whole character, still there would be a valiant remnant that had done it. These are commonplaces, precisely of the moral outlook upon life. When we come to the moral fountainhead we come to what the man is, at a particular time, as measured by what he does or is disposed to do with his power of volition. It is fantastic to say that he finds his character on his hands. It is nothing but the moral description of himself. It is that self alone that wields his hands. The indeterminist is disquieted (through a mental confusion) by the discovery that the nature antedates the act, that virtue antedates the virtuous decision. (For that contains in itself the whole logical essence of the difficulty about origin.) And that lies in the signification of the terms. If we fancy that there would be any gain (or any meaning) in circumventing this order, we delude ourselves. The final fact we esteem or disesteem in a man is some subsisting moral quality. Morality has its eye upon acts, but an act is fleeting, it cannot be treasured and cherished. A quality can be, it lasts. And the reason why it is treasured and cherished is that it is the source of acts. Our treasuring and cherishing of it is (in part) our praise. It is the stuff certain people are made of that commands our admiration and affection. Where it came from is another question; it is precious in its own nature; let us be thankful when it is there. Its origin cannot take away its value, and it is its value we are recognising when we praise.

The peculiar importance that attaches to this "stuff" lies in its peculiar properties, so to 
speak. It is not a fixed "article of value", but lives, moves about in "this raging and confounding universe", this maze of unstable circumstances, yet can acquit itself with some fitness in face of all of them; reveals itself by choosing and rejecting with open eyes; steers its way through the dangers and complications, able to compare acts in advance, conscious of good and evil, allured to do otherwise but electing to do thus; good in a very special manner, in that it consciously cleaves to the good. A reliable character in the midst of unreliable circumstances. Consciousness, foresight, intelligence, moral consciousness, and sound choice. A unique "stuff".

The indeterminist, we noticed, requires a man to be "an absolute moral source" if we are to commend him. Well, if he were so, what could we say about him but what kind of a source he was? And he is so in fact. Suppose now that this source has in turn a source - or that it has not! Does that (either way) change what it is?

"But moral severity! How can we justly be severe toward a mere fact in nature - in human nature?" Because it is evil; because it must be checked. If somebody takes pleasure in torturing an innocent person, we spring to stop the act; to hold back the perpetrator, if need be with violence; to deter him from doing it again, if need be with violence; to warn any other possible perpetrators: "This shall not be done; we are the enemies of this conduct; this is evil conduct." At what could we be indignant but at a fact in somebody's human nature? Our severity and enmity are an active enmity to the evil; they are all part of that first spring to stop the act. "Society is opposed in every possible manner to such cruelty. You shall be made to feel that society is so, supposing that you cannot be made to feel yourself the vile-ness of the act." It does not remove our sense of its vileness to reflect that he was acting according to his nature. That is very precisely why we are indignant at him. We intend to make him feel that his nature is in that respect evil and its expression insufferable. We intend to interfere with the expression of his nature. That what he did proceeded from it is not a disturbing and pause-giving consideration in the midst of our conduct, but the entire basis of it. The very epithet "vile" assumes that his behaviour arose from an intention and a moral quality in the man. How can we justly be severe? Because he ought to be checked and deterred, made to feel the moral estimate of what he has been doing. This we consider more fully under the topic of Desert.

Compare a case where the wrongdoing, whatever it be, is one's own. Catch a man in a moment of fierce self-reproach, and bring the objection above before him. Would it relieve him of his feeling? It would be an irrelevant frivolity to him. He is shocked at a wrong that was done and at himself for doing it; he repents of the acts of will that brought it about; he would gladly so change himself as never to do the like again; he is ready to "beat himself with rods". With all that the metaphysical entanglement has simply nothing to do.

It would follow from the objector's way of thinking that if a man's moral state at one time was produced by himself through previous efforts, then our praise or blame must shift back to the earlier moral state and be applied to that alone; or, if that again was such a product, must shift still further back and be confined to the state that began the process. This is a vital misconception. The man in each of the moral states in the series may justly be characterised as good or bad, in this respect or that, in proportion as we truly know him; according to his decisions and intentions, or tendencies thereto, as compared with his then situation and knowledge of what he confronts, and of the effects that may fairly be expected from acts. This is implied whenever we make the remark that someone has deteriorated or improved in character; in other words, he is 
less or more to be praised now than he was formerly.

I say, "as compared with his then situation", for of course, in seeking to know what the forces of his character in themselves really are, we must take full account of the hardships, the exasperations, provocations to passion, causes of fatigue, etc., that enter into that situation. As regards the source of any moral degeneration, we cannot and do not call a person good because we can see that it is evil circumstances that have made him bad; nor do we refrain from deeming him bad, since he is so; but we may have gained thereby a better insight into the hidden potential forces of his character, and see, in view of the previous circumstances, that it is at root less bad than we might have supposed. And while deeming him bad we may profoundly pity him in his wretched fortune.

"Still, does not determinism force us to face a fact in some sort new to us, that the offending person came to act so from natural causes; and does not that of necessity alter somewhat our attitude or state of mind about moral judgment?" Why, the fact is not new at all. In daily life we are all determinists, just as we are all libertarians. We are constantly attributing behaviour to the character, the temperament, the peculiarities of the person and expecting him to behave in certain fashions. The very words of our daily converse, as we have so amply observed, are full of determinism. And we see nothing inconsistent in being aware at the same time that he is free in choosing his course, as we know ourselves to be. We merely form expectations as to what he will freely choose. Nor do we see anything inconsistent in blaming him. At the very moment when we do so we often shake our heads over the environment or mode of life or ill-omened pursuits that have brought him to such ways and to being a blameworthy person. To be sure, in that economy of thought which is one of the salient traits of humanity, we seldom trouble ourselves to trace back with any attempt at thoroughness another's life, education, early temperament, etc. We do not go far back, but we are attentive, as we have to be, to his disposition and spirit in the present, at least as objectively expressed and thence imputed. And that is sufficient to include the whole point at issue. We recognise the one essential fact, that the nature precedes the act, and that the nature is simply a "given" fact in the world (not originally created by the agent himself - a would-be notion that visits the mind only in an attack of logical vertigo). Indeed, since blame is in itself the assertion of a particular nature existent in the world and father to an act, blame has contained in itself the truth in question from the beginning.

To be sure, determinism as a philosophic doctrine, determinism so named, may come as a new and repellent idea to us. We have been thinking in the right terms of thought all the while, but we did not identify them with terms of causation; when the philosophical names are put upon them we recoil, not because we have a false conception of the facts, but a false conception of the import of the philosophical terms. When we feel that somebody could have done otherwise but chose to do a wrong act knowingly, then we one and all feel that he is culpable and a proper object of disapproval, as we ought to feel. We merely have not been schooled enough in the application of general terms to call the course of mental events within him causation. So again, goodness consists in qualities, but the qualities express themselves in choosing, which is unfettered and so often trembles in the balance; when we are suddenly confronted with the abstract question, "Can we be blamed for a quality we did not choose?" the colours run and the outlines swim a little; some disentanglement of abstract propositions is required, though we think aright in practice on the concrete cases. So all that philosophic determinism "forces us to face" is the meaning of our terms. No, it is the opposite doctrine that 
must revolutionise our attitude toward moral judgments. If it is true, we must come to see that no moral severity toward the helpless subject of an act-of-will that he suddenly finds discharging itself within him, though not emanating from what he is or prefers, can be deserved or relevant. To comprehend all is to pardon all - so far as it is undetermined. Or, rather, not to pardon but to acquit of all. However, in face of the actual facts, there is something that does bring us to a larger than the usual frame of mind about indignation and punishment and the mood of severity. And that is thought, sympathetic thought, any thought that enters with humane interest into the inner lives of others and pursues in imagination the course of them. In an -outbreak of moral indignation we are prone to take little cognizance of that inner life. We are simply outraged by a noxious act and a noxious trait (conceived rather objectively and as it concerns the persons affected) and feel that such act should not be and that such a trait should be put down. The supervening of a sympathetic mental insight upon moral indignation is not a displacement, but the turning of attention upon facts that call out other feelings too. To comprehend all is neither to pardon all nor to acquit of all; overlooking the disvalue of acts and intentions would not be comprehension; but it is to appreciate the human plight; the capacity for suffering, the poor contracted outlook, the plausibilities that entice the will. This elicits a sympathy or concern co-existing with disapproval. That which is moral in moral indignation and behind it, if we faithfully turn to it and listen, will not let us entirely wash our hands even of the torturer, his feelings and his fate; certainly will not permit us to take satisfaction in seeing him in turn tortured, merely for the torture's sake. His act was execrable because of its effect on sentient beings, but he also is a sentient being. The humanity that made us reprobate his crime has not ceased to have jurisdiction. The morality that hates the sin has in that very fact the secret of its undiscourageable interest in the sinner. We come, not to discredit indignation and penalty, nor to tamper with their meaning, but to see their office and place in life and the implications wrapped up in their very fitness. Of this more presently.

Amongst qualities none, of course, is higher than that which masters strong impulsive tendencies within ourselves that we decide not to tolerate. It is the possibility of this desperate inner struggle of self-overcoming, the genuine possibility of defying habit and weakness and asserting new life, which has caught and held the indeterminist's mind; but which he formulates loosely. He wishes to conceive of a self that need have no capital stock of qualities at all on which its volition depends. He thinks, or imagines that he thinks, of virtue as a thing nobly arising in the moment. In fact it is a thing nobly manifested in the moment; roused perhaps, brought to active life though it seemed dead, but still in some form pre-existing. What he admires is admirable, but he does not stop to think out its nature. To be "the author of novelties" is as possible, as fruitful for society, as challenging to the spirit as he deems it; but that author must exist as author, must have it in him to make a break for the new. The indeterminist would promptly retort that this is evidently not the sort of novelty he has in mind, that he means a moral act which is not an effect of anything pre-existing in the person. To which I answer: The novelty interesting to morality and to humanity is the escape from the spell of habit or ease or a straitened mental outlook, the leap of the soul with all its strength in a new direction; the question of causal nexus is of interest only to the philosophical analyst. The determinist's analysis leaves the escape from habit, etc., entirely possible and as creditable as it seems. On the indeterminist's account it would be a cosmological accident without moral significance. 
Responsibility. - Again, it is said that determinism takes from man all responsibility. As regards the origin of the term, a man is responsible when he is the person to respond to the question why the act was performed, how it is to be explained or justified. That is what he must answer; he is answerable for the act. It is the subject of which he must give an account; he is accountable for the act. The act proceeded from him. He is to say whether it proceeded consciously. He is to give evidence that he did or did not know the moral nature of the act and that he did or did not intend the result. He is to say how he justifies it or if he can justify it. If the act proceeded from him by pure accident, if he can show that he did the damage (if damage it was) by brushing against something by inadvertence, for example, then he has not to respond to the question what he did it for - he is not consciously responsible - nor how it is justified - he is not morally responsible, though of course he may have been responsible in these respects for a habit of carelessness.

But why does the peculiar moral stain of guilt or ennoblement of merit belong to responsibility? If an act proceeds from a man and not merely from his accidental motion but from his mind and moral nature, we judge at once that like acts may be expected from him in the future. The colour of the act for good or bad is reflected on the man. We see him now as a living source of possible acts of the same kind. If we must be on our guard against such acts we must be on our guard against such men. If we must take steps to defend ourselves against such acts we must take steps to defend ourselves against such men. If we detest such acts, we must detest that tendency in such men which produced them. He is guilty in that he knowingly did evil, in that the intentional authorship of evil is in him. Because the act proceeded in every sense from him, for that reason he is (so far) to be accounted bad or good according as the act is bad or good, and he is the one to be punished if punishment is required. And that is moral responsibility.

But how, it is asked, can I be responsible for what I will if a long train of past causes has made me will it - the old query asked anew in relation to another category, responsibility, which must be considered separately. Is it not these causes that are "responsible" for my act - to use the word in the only sense, says the objector, that seems to remain for it?

The parent past produced the man, none the less the man is responsible for his acts. We can truly say that the earth bears apples, but quite as truly that trees bear apples. The earth bears the apples by bearing trees. It does not resent the claim of the trees to bear the apples, or try to take the business out of the trees' hands. Nor need the trees feel their claim nullified by the earth's part in the matter. There is no rivalry between them. A man is a being with free will and responsibility; where this being came from, I repeat, is another story. The past finished its functions in the business when it generated him as he is. So far from interfering with him and coercing him the past does not even exist. If we could imagine it as lingering on into the present, standing over against him and stretching out a ghostly hand to stay his arm, then indeed the past would be interfering with his liberty and responsibility. But so long as it and he are never on the scene together they cannot wrestle; the past cannot overpower him. The whole alarm is an evil dream, a nightmare due to the indigestion of words. The past has created, and left extant, a free-willed being.

Desert. - But we have not come to any final clearness until we see how a man can be said to deserve anything when his acts flow from his wishes, and his wishes flow from other facts further up the stream of his life. There is a peculiar element in the idea of deserving. This is the element of "ought". A man deserves 
punishment or reward if society ought to give it to him; he deserves the punishment or reward that he ought to receive. We cannot say universally that he deserves what he ought to receive, but only when it is a question of reward or punishment.

What treatment a man should receive from society as a result of wrongdoing is a question of ethics. It is widely held that an evildoer deserves punishment, not only for the defence of society but because there is an ultimate fitness in inflicting natural evil for moral evil. This, as we know, has been maintained by determinists. Since the idea of desert collapses altogether on the indeterminist's conception of conduct, this theory of the ground of desert cannot be said to be logically bound up with indeterminism. For my own part, however, owing to reasons for which I have no space here, I cannot hold the theory. I believe that the ideal ends of the administration of justice are (1) to see that all possible restitution is made, (2) to see as far as possible that the malefactor does not repeat the act, and (3) so far as possible to render the act less likely on the part of others. And these ends should be sought by means that will accomplish them. Morality is humane. It is animated by good-will toward humanity. Our instinctive impulse to retaliation must be interpreted with a view to its function in society, and so employed and regulated to the best purpose. Being a part of the defensive and fighting instinct, its functional aim is evidently to destroy or check the threatening source of evil - to destroy the culprit or change his temper. Our common and natural notion of desert is in harmony with either of these views; only on the second it receives a supplement, a purposive interpretation.

We discover punishment not only in combat but in nature at large. If a child puts its hand into flames it is burnt. After that it puts its hand into flames no more. Nature teaches us to respect her by punishments that deter. Society, to preserve itself, must find deterrents to administer to men. It must say, "I'll teach you not to do that." Already nature has taught it such deterrents. Society must shape men's actions or at least rough-hew them, to the extent of striking off certain jagged and dangerous edges, and the most obvious way to do so is by penalties. A secondary way is by rewards, and these nature has taught also.

When a man needlessly injures others, society by punishment injures him. It administers to him a specimen of what he has given to others. "This," it says, "is the nature of your act; to give men suffering like this. They rebel at it as you rebel at this. You have to be made more acutely conscious of the other side; the side of the feelings and the forces that you have outraged. You have to be made to feel them recoil upon you, that you may know that they are there; You have to be made to respect them in advance. And others like-minded to respect them in some degree better by seeing how they recoil upon you."

But this is only a method of working upon him and them; it is justified by effectiveness alone. It supposes two things; that society has been just in the first instance to these men themselves, that is, that they were not drawn by unjust conditions of life into the acts for which they are made to suffer; and that the suffering will in fact improve their conduct or that of others. The truth is that society often punishes when it is itself the greater malefactor, and that the penalty, instead of reforming, often confirms the criminality. It is due to nothing but the crude state of civilisation that we have added so little of a more sagacious and effectual mode of influencing criminals and preventing crime than the original and natural method of hitting back.

Out of this situation arises a subsidiary sense of deserving. A man may be said to deserve a 
punishment in the sense that, in view of the offence, it is not too severe to give him if it would work as above conceived; though if we believe it will not so work it ought not to be given him.

It is here that we confront the school that would sweep away all notions of desert, all indignation, whether against public or private offenders, on the ground that free will and responsibility are illusions, and would substitute the moral hospital for the prison. Tietjens, for example, would have us apply "de-suggestion" to rid ourselves of the heartburnings and disquiet that imputing moral responsibility brings upon us. It is a pity that a teaching which speaks to us in the name of advanced psychology should be founded on a hasty and crude analysis. If we did not acquire the idea of free will from our experience of the conditions of our own volition, how did we come by it at all? Under the laws of origin of our conceptions, how were we able to conceive an elementary type of volition that has no counterpart in real life? How could we fabricate the idea without any material for it? What these determinists do is, first, to make the unthinking concession to the indeterminists that they have a coherent theory and that it is one with the naive belief in free choice; having hastily conceded so much, they are constrained to call the naive notion an illusion. They do not see the strength of their own fundamental position.

Honour and dishonour will never be withdrawn from morals. We shall not cease to look out upon our world with appropriate emotions. But it behooves us to take care that they are appropriate. The moral emotions are often barbarously and with terrible effect misapplied; it shows what they could do if intelligence guarded their application. The Christian principle of hating the sin because it is in fact noxious, but bearing good-will to the sinner and preferring his reformation with a minimum of suffering to his punishment, is surely the root-principle. And here it is that the school of cool realism, of the medical, educational, and environmental treatment, brings fresh air and aid. It wants to discover effectual means to what is in truth a chief part of the moral end. We shall not be troubled by its shallow philosophy in so far as it can help to that end.

If the general view here taken, which seems forced upon us in the prosaic process of examining words, is correct, then as we look back over the long course of this controversy and the false antithesis that has kept it alive, how can we help exclaiming, "What waste!" Waste is surely the tragic fact above all in life; we contrast it with the narrow areas where reason and its economy of means to ends in some measure reign. But here is huge waste in the region of reasoning itself, the enemy in the citadel. What ingenuity, what resource in fresh shifts of defence, what unshaken loyalty to inward repugnances, what devotion to ideal values, have here been expended in blind opposition instead of analysis. The cause of determinism, seeming to deny freedom, has appeared as the cause of reason, of intelligence itself, and the cause of free will, seeming to exclude determination, has appeared that of morals. The worst waste is the clash of best things. In our subject it is time this waste should end. Just as we find that morality requires intelligence to give it effect and remains rudimentary and largely abortive till it places the conscience of the mind in the foreground, so we find that determinism and the faith in freedom meet and are united in the facts, and that the long enmity has been a bad dream.

\section{Bibliography}

Eddington, Arthur S. "Physics and Philosophy." Philosophy 8.29 (1933): 30-43. Print. 
Hobart, Richard E. "Free Will as Involving Determination and Inconceivable without It." Mind (1934): 1-27. Print.

Moore, George Edward "G. E.". "Free Will." Ethics (1912): 84-95. Print.

Sidgwick, Henry. "The Methods of Ethics. 7th." Hackett (1981). Print. 